\title{
The Housing Lifeline: A Housing Affordability Policy
}

\author{
Joshua Gans and Stephen King
}

$\mathrm{H}$ ousing affordability, particularly for low-income households, is a major public policy concern. This paper considers the basis of the affordability problem and potential solutions. In contrast to other work, we distinguish between long-term and short-term affordability and focus on short-term income fluctuations that may create affordability problems for low-income families. Our goal is not to review existing housing policies for low-income households. Gans and King (2003) includes such a review. Instead we highlight the nature of the short-term affordability problem and consider associated market failures. Our chief contribution is to suggest an innovative policy response - The Housing Lifeline - that uses an income contingent 'loan' to fund assistance for lowincome households in overcoming problems associated with short-term housing affordability. We consider both the theoretical basis for the housing lifeline and a variety of issues relating to its practical implementation. In particular, we note that a housing lifeline may have a variety of economic benefits relative to existing housing policies.

Recent concerns over housing affordability have reflected rising house prices. The Australian Bureau of Statistics (2002) reported that over the three years from July 1998 to June 2001 the weighted average price of existing dwellings in Australia's capital cities rose by almost 8 per cent per year. While these increases reflect general prosperity in Australia, this prosperity has not been evenly distributed over the population. Rising house prices can lower the affordability of housing to those families who are at the lower end of the income distribution.

What, however, is actually meant by housing affordability? How do we judge if low-income families are facing an affordability problem for housing? If there is an affordability problem, is this due to a rise in housing prices relative to other goods and services or a fall in the relative income of the poorest in society? It is well accepted in Australia that governments should take an active stance in alleviating poverty and the hardships faced by low-income families. But an antipoverty program is different from a housing policy and the linkage between the two may be very weak if an apparent fall in housing affordability for the poor actually reflects a reduction in real income for the poor rather than a rise in the relative price of housing.

In the next section of this paper, we discuss the nature of low-income housing affordability, before focusing explicitly on short term affordability issues. We then present and discuss the housing lifeline in detail.

Joshua Gans and Stephen King are Professors at the Melbourne Business School and Department of Economics, The University of Melbourne. 


\section{The Affordability Problem}

Affordable housing is usually defined with reference to the (post tax) income that is sufficient to meet household basic needs (food, clothing, medical care, etc.). Under this definition, if a household is spending more than 25 percent (for rent) to 30 percent (for mortgage repayments) of its income on housing, then that household is experiencing an affordability problem.

This definition could apply to high-income households who spend a lot on housing. Thus, this benchmark on affordability is usually only applied to households that fall into the bottom 40 percent of the overall distribution of income. In Australia in 2001 the affordability threshold based on 30 per cent of the second quintile of average weekly household income was only \$141 compared with the median weekly rent in Australia of $\$ 183$ and a median weekly mortgage repayment of $\$ 230$ (see Gans and King, 2003). Berry and Hall (2001) determined that around 70 per cent of private tenants in the bottom 40 per cent of the overall distribution of income paid more than 30 per cent of household income on rent. This proportion was higher in Melbourne and Sydney.

This approach to housing affordability, however, does not allow us to easily distinguish between a housing problem and a low-income problem (Glaeser and Gyourko, 2002). Moreover, it does not take into account the period of time over which there is an affordability problem. Relevant policies to deal with housing affordability will generally depend on whether it is a long-term structural problem or a temporary situation.

\section{Long-Term Versus Short-Term Affordability}

Affordability problems fall into two classes: long and short-term. The long-term affordability problem involves households who, for the foreseeable future, will be unlikely to have an income that would allow them to purchase appropriate housing services. The short-term affordability problem concerns households who over time have an average income that would be sufficient to purchase appropriate housing in the private market, but who face short-term fluctuations in income that precipitate housing stress or crises. That is, a household may face the short-term loss of employment, illness of a primary income provider or a rise in interest rates or rents precipitated by macroeconomic conditions. Such households may find themselves unable to afford their current accommodation in the short-term and face hardship from being forced to move; losing personal capital incorporated into their homes. These short-term fluctuations harm both the households and the parties providing them with housing. As a result, households with a higher risk of short-term income fluctuations may find it difficult to gain appropriate housing in the private market.

The long-term and short-term affordability problems have different causes and, hence, require different policy approaches. The long-term problem is a problem of low income as opposed to an issue of housing policy per se. Government interventions that are designed to improve conditions in the housing 
market are no solution to this type of problem: there is no sense in improving the operation of a market that these households cannot effectively access. The longterm affordability problem requires anti-poverty programs with housing as a key element. For this reason, while it is an important aspect of overall social welfare programs, the long-term affordability problem is not the focus of this paper.

The short-term problem is caused by income fluctuations rather than a permanent lack of income and it requires a mechanism to deal with short-term income loss. This is a concern for government if private markets are unable to provide adequate solutions to housing stress caused by income uncertainty. While, in principle, capital markets should be able to provide short-term finance to get households through rough patches, in practice, this does not occur. The main economic reason for this is that, for quite understandable reasons, banks and other lenders are reluctant to extend loans to households that have just suffered a dramatic loss of income or a rise in housing prices.

\section{Market Imperfections and Short-Run Affordability}

The market failures associated with long-run affordability problems are wellknown: focussing on the indivisibility of housing assets, externalities between housing submarkets, government regulation and taxes and the slow response of supply to changes in demand. For short-run affordability, the potential market imperfections that generate a need for government intervention have not featured in housing policy. For this reason, we briefly review those market failures below.

\section{Financial and rental market imperfections}

Housing market and financial markets are closely connected. In theory, financial markets should provide finance to potential homeowners and investors who are likely to be able to make the relevant repayments. However, financial markets suffer from problems of asymmetric information that may lead to market failures and credit rationing (for example, Stiglitz and Weiss, 1981).

Information problems arise in financial markets because potential lenders may have difficulty distinguishing between individuals who can make repayments and those who cannot. As a result, potential lenders may be reluctant to provide funds to customers who appear more risky; for example individuals with a lack of credit history or who are proposing more risky investments.

The underlying problem here is asymmetric information, not risk. After all, risk accompanies all lending and, in the absence of information asymmetries, would simply be reflected in higher interest rates to more risky borrowers. Rather, the problem is that the potential lender cannot adequately distinguish between high and low risk borrowers and so may be reluctant to lend any funds. Further, this problem cannot be solved by simply raising the interest rate on borrowed funds. Raising interest rates may simply act to dissuade the low risk borrowers leaving only the high risk borrowers. After all, the high risk borrowers, who know that there is a higher chance they might default on the loan, will be less influenced by 
interest rates. In this way, a simple interest rate charged equally to all potential borrowers, adversely selects for borrowers with a higher risk profile. To attempt to solve this problem a lender might try to ration credit; attempting to infer borrower risk through indirect means.

In financial markets that provide housing funds, information asymmetries mean that low-income households, particularly those with a chequered history of employment, will tend to be excluded from access to housing finance. Financial institutions may minimize adverse selection risk by shifting risk back on to the borrower, for example by requiring a large deposit on a house before funds are provided. This reduces the risk that the financier will be stuck with a house that is valued at less than outstanding debt if default occurs. Low-income households will find such a deposit hurdle difficult to meet as they are least able to save for a significant housing deposit while at the same time paying for rental housing. Overall, this means that credit rationing is likely to have the greatest adverse effect on low-income households.

Similar adverse selection problems arise in rental markets. Investors are keen to rent properties to households or individuals who will be able to pay the relevant rent and who will not impact too heavily on the depreciation of the dwelling. But landlords cannot determine the exact risk associated with particular tenants and will try to infer this risk from other factors. Again, an obvious method used by investors to distinguish between tenants is their employment history and their current job and income. This discriminates against low-income households who are viewed as having a higher risk by landlords and makes the rental prospects for low-income households less certain than those for higher income households.

Economic discrimination in both financial and rental markets biases those markets against low-income earners. This discrimination need not reflect any bias on the part of lenders or landlords. Rather it is simply a rational attempt by lenders and landlords to at least partially overcome information asymmetries. However, the end result may be to ration many low-income families out of the private markets for housing. Put simply, the market imperfections can make housing unobtainable for low-income households.

\section{Income risk and affordability}

While market imperfections reduce access to private housing markets for lowincome households, even if a low-income household is able to gain appropriate housing, either as tenants or owner-occupiers, these households remain particularly vulnerable to future income risk.

Income risk is something that faces all households. It can arise through a number of sources. For example, unemployment is usually associated with a significant but temporary drop in income for individuals and households. Injury or significant illness can also lead to a sudden reduction in income.

An unforeseen drop in income can lead to a large but temporary reduction in housing affordability for the relevant household. For example, if the household is renting, then it may be impossible for the household to make its regular rental 
payments when it suffers a sudden reduction in income. In such circumstances, the tenants face eviction. Similarly, recurring mortgage payments may not be met due to a sudden income shock, leading to potential foreclosure.

Income risk, like any other form of risk, can be reduced by insurance. For example, income protection insurance is available to households. Similarly, both landlords and lenders may be willing to renegotiate agreements to overcome shortterm income shocks. After all, finding new tenants or foreclosing on a mortgage and selling a property are both expensive activities. Both landlords and lenders have incentives to take actions to avoid incurring these expenses. Finally, households may self-insure against income risk, for example by keeping ahead of mortgage payments or by keeping a readily accessible pool of savings.

These solutions to reduce the cost of income risk, however, are less likely to be available to low-income households. For a household with a history of unemployment, income protection insurance is likely to be either unavailable or prohibitively expensive. The moral hazard problem facing the insurer makes such insurance not viable. Self-insurance through discretionary saving is difficult, if not impossible, for low-income earners. And renegotiation to avoid foreclosure or eviction is less likely to occur for higher risk, marginal households. Consequently, low-income families are likely to face significant residual income risk that creates short-term housing crises for these families.

\section{The Housing Lifeline}

The income risk faced by low-income households feeds into the two housing market failures discussed above. Income risk directly leads to short term dislocation and cannot be fully addressed by private insurance due to moral hazard. A history of low, variable income can be rationally used as an economic discriminator by landlords and housing financiers seeking to overcome issues of adverse selection.

How should the government address this problem of income risk? Unable to meet rental or mortgage payments, low-income households faced with short-term income distress can face the loss of appropriate housing. Current assistance programs, however, are not well equipped to deal with short-term distress. For example, Federal government rental assistance in Australia only becomes relevant once a household becomes eligible for other forms of benefits. In the US, Section 8 voucher programs often involve waiting lists, meaning that they are unable to meet the needs of low-income families facing short term distress.

Existing policies for low-income housing are often designed for households that not only have low income today, but are destined to remain on low incomes forever. Further, the eligibility criteria for these programs often create poverty traps that exacerbate the plight of low-income families over the longer term. In other words, the programs are means tested so that a low-income family who has a rise in income can face punitive effective taxation rates as their benefits rapidly diminish with the rising income. 
Rental and interest guarantees provide one way to help overcome market failures for low-income households. These types of programs help to remove the risk from lenders and landlords. However, these programs often lack flexibility and cannot address income shocks when they arise.

An alternative approach would involve governments addressing the income risk associated with low-income households directly. In particular, the government could provide a form of income insurance to low-income families, to ensure that short term income fluctuations do not create long term housing problems. For example, the government might allow a household that has suffered a short-term drop in income, due to say unemployment or temporary lay off, to draw down a payment (say up to an eventual maximum of $\$ 5,000-\$ 10,000$ ) towards rental or mortgage costs.

How would such insurance work? After all, if an individual is unemployed, they can (after the relevant waiting period) receive unemployment benefits and rental assistance. Isn't this already a form of government income insurance? Yes: these benefits are not explicitly designed as insurance but conflate the goals of short-term and long-term assistance. In addition, housing stress can arise for income shocks not necessarily the result of unemployment (for example, sickness or profit reductions for small business owners). From the perspective of providing income insurance for low-income households, existing rent assistance does not address short-term income fluctuations, requires low-income households to draw down (possibly non-existent) savings while waiting for eligibility, fails to offer security to lenders and landlords, and creates undesirable incentives for the lowincome household as it tries to overcome the temporary setback.

In this section, we consider an alternative approach that we call a 'housing lifeline.' This is essentially a government provided insurance product. It has a number of similarities to the Higher Education Contribution Scheme (HECS) in that it is based on lifetime income rather than current income, it limits the impost on government funds while providing short-term relief for relevant households and it is a product where benefits are determined by the needs and requirements of the low-income household themselves.

\section{The basic concept of a housing lifeline}

Suppose that a household suddenly finds itself facing a crisis where it is unable to meet short-term commitments for housing payments. With a housing lifeline the household would be able to draw down a payment from the federal government to tide it over the short-term crisis. This payment would be a loan to the household and the household would incur a future tax liability associated with the loan. The payment of this liability would be tied to future income, like the HECS. Further, the liability may or may not have a reduced interest rate associated with it, depending on government policy. For example, the lifeline might have an interest rate equal to the long-term government bond rate. This is likely to be substantially below equivalent interest rates available to low-income families. 
Payments to a household would be capped. The housing lifeline is designed to provide short-term relief, not to provide a permanent source of support for those families who will not have the means to adequately fund housing in the medium to long-term. Thus, the lifeline does not replace other long-term poverty programs but supplements these programs providing more appropriate assistance to lowincome households facing temporary crisis. The payments may be capped on both a weekly and a total basis. For example, it might be possible to 'borrow' up to $\$ 200$ per week under the cap up to a total of $\$ 10,000$. Thus, the scheme would provide up to 50 weeks (or more if less than $\$ 200$ was drawn upon) support for a relevant household. The cap would also apply over successive periods of crisis, so that a household would not be able to build up more than say $\$ 10,000$ of debt at any time.

We envisage that the payments under a housing lifeline would be tied to housing. Thus, funds would be paid directly to a (registered) landlord or lender specified by the relevant household. This would require a contractual agreement that ensures that the funds do reduce the household's liability to landlords and lenders directly. At present, Medicare payments operate in this manner.

Drawing down the lifeline would be a choice made by the relevant household. But because this access to an instant 'line of credit' removes a substantial amount of the risk that would otherwise face lenders and landlords who provide housing solutions to low-income families, the lifeline directly addresses the problems embedded in the rental and mortgage markets.

The risk, of course, does not disappear, but it is both reduced and it is passed onto the government. The risk is reduced because the government takes on a portfolio of 'loans' to low-income households. Unlike an investor with only one or two properties, the government can pool the risk of income loss for low-income households, reducing the idiosyncratic variability of that risk.

It is recognised that there are significant differences from the government's perspective in the positions of people who are in housing stress because they cannot meet their mortgage payments and those who cannot pay their rent. The housing lifeline proffered to a struggling mortgagor can readily be constituted as a second (or third) mortgage ensuring that the government has some real security for its advance over and above the promise of the borrower to repay. Advances to a struggling tenant are supported only by the obligation of the borrower to repay and that of course being contingent on earning sufficient income in the future to enable him or her to do so. It is for that reason that government may consider this housing lifeline is best first tested with those in the process of buying homes. The government might, for example, introduce the housing lifeline for home buyers at the same time as it reduces or removes the current first home buyer grant. As a policy to help low-income households, the housing lifeline is clearly better targeted than the general first home-buyer grant.

While the government takes on board the risk associated with low-income households, through the housing lifeline insurance, the government is also in a good position to deal with that risk. The government has the substantial advantage of ensuring appropriate repayment of any lifeline loan through the taxation 
system. A low-income household can use the lifeline in periods of crisis and then repay the loan when its circumstances improve. This may be in the short-term or in the longer term, depending on the relevant household's circumstances. For example, modest repayments to the government may begin when household income approaches a set level above poverty-line income.

This illustrates the basic concept of the housing lifeline. However, a myriad of practical issues present themselves. In what follows we provide some answers to natural questions that arise.

\section{Government responsibility}

A housing lifeline would most sensibly be a federal government initiative. A key reason for this is that the federal government controls the income taxation system that would be used for lifeline repayments.

In addition, the federal government is the obvious instigator as the lifeline would need to be incorporated into the existing federal social security system to avoid households 'double dipping' and to ensure consistency between systems of assistance. The lifeline would apply across Australia and would be integrated with other welfare payments. Indeed, the housing lifeline would make some parts of the existing federal social security safety net redundant in the short-term. For example, if the lifeline applied to renters as well as home owners then it would at least partly replace existing rental assistance provided by the federal government.

\section{Funding of the lifeline}

In principle, the housing lifeline could be self-funding. So long as the interest rate charged by the government is above the long-term bond rate on government funds and accumulated debt is eventually repaid, the government will be operating on the same funding principles as any lender.

In practice, however, full repayment from every household will not be possible. Some households will move from temporary to long-term crisis and will be unlikely to ever gain a lifetime income that would allow repayment. In such a situation, the household can be transferred onto appropriate long-term benefits after the lifeline expires or when the long-term nature of the crisis becomes evident. Further, to the extent that the government subsidises the lifeline interest rate (especially in situations where the crisis is protracted), the repayments will be less than the financial cost of the associated funds.

At the same time, because the lifeline aids households in temporary crisis and provides appropriate short-term assistance to these households, it can help these households avoid becoming reliant on more long-term government assistance. The timely and temporary intervention allowed by the lifeline can help households avoid long-term problems, with the associated long-term government payment of benefits. 


\section{Eligibility for the lifeline}

We envisage that the housing lifeline be available to households with insufficient financial assets (as defined by a means test) to utilise to overcome short-term housing crises. The financial assets would include equity in properties (other than the family home), shares and other financial assets but not superannuation (which is currently illiquid).

The idea of basing eligibility on an asset rather than income test goes to the heart of the lifeline concept. An income test is inappropriate because (1) it is income that is fluctuating and generating the need for a lifeline (so it is unclear what the appropriate measure of income would be); and (2) income-based eligibility tests have the potential to create poverty traps. On the other hand, assets are a proxy measure of lifetime income and wealth accumulation. Thus, for the same reason that these are used for eligibility to old-age pensions, they are an appropriate sorting mechanism for who should be entitled to a housing lifeline.

\section{Maximum debt allowed}

The basic idea of the housing lifeline is to insure households against loss of housing during short-term fluctuations in income. The level of debt allowed will be related to the period of time the household is in crisis as well as the level of liabilities in terms of rent and loan repayments it faces. Evaluating this would require more information regarding the length of time and level of payments that could see an average low-income household through a crisis.

Suppose it was determined that typical housing stress can take 12 to 18 months to overcome and required payments of $\$ 100$ to $\$ 200$ per week. This suggests that a maximum debt of between $\$ 10,000$ and $\$ 15,000$ would be sufficient to cover this period. Nonetheless, the exact amount would really require a careful examination of the reality of housing stress.

Adjustments would also have to be made for the number of people in the household (in particular, the number of dependents). This, however, is something that is currently dealt with through the social security and taxation system and could carry over to the housing lifeline.

\section{Rate of interest to be charged}

We envisage that debt accruing under a housing lifeline would be subject to interest that would compound over the life of the debt. To break-even, the scheme would have to charge an interest rate exceeding the rate on long-term government bonds to take into account the debt that is never repaid. However, it is likely that the interest rate in this situation will still be less than market rates on home and other lending available to low-income households.

In principle, the lifeline need only provide a 'no questions asked' access to normal market lending rates that might not otherwise be available to households in crisis. This would avoid any credit rationing that might otherwise occur. In this 
situation, the government may actually generate long-term revenue from the scheme.

It is also possible that the interest rate could be lower than market rates or even below a break even rate. In this case, the scheme would provide a subsidy to low-income households.

The level of interest rate ultimately depends upon whether the government wishes to use the lifeline as just pure insurance or something more. This is not a policy judgment that can be made here.

\section{Exhaustion of household lifeline resources}

A household that remains in crisis for a longer period of time will exhaust its lifeline resources. In this situation, closer intervention will be required. This could be in the form of a review that extends the loan or it could involve moving the household to other social security and housing plans designed to deal with long-term low income. It needs to be emphasised that the housing lifeline is designed to provide assistance to short-term loss of income and housing stress. Long-term issues need to be addressed through other means.

\section{Effect of lifeline on household incentives}

Ordinary government housing assistance can create a poverty trap. That is, if the assistance is income based, when incomes rise, households may face very high marginal tax rates. This, in turn, reduces household incentives to find employment or otherwise restore income to its previous level.

Because the lifeline repayment is based on a notion of lifetime income rather than current income, it is less likely to create a poverty trap. While repayments through the taxation system will create income zones where the household faces slightly higher taxation rates than otherwise (for example, a 10 per cent increase), these changes are small compared to the effective marginal taxation rates under, for example, rent assistance schemes. Thus, a housing lifeline can retain incentives for households to take appropriate actions and risks to improve their standard of living.

The lifeline is based on a loan, not a gifted payment, so there are reduced incentives for higher income households to try and abuse the system. For example, in the simplest scheme a household only needs to provide a tax file number and appropriate identification to access the lifeline. But repayment begins as soon as the household income exceeds a certain level. A household earning income above that level has little incentive to 'borrow' funds then immediately repay them through the taxation system. If such a problem arose it could be addressed through a penalty charge on households if taxable income exceeded a specific level in the year that the lifeline was drawn down. 


\section{Responsibility for the debt}

Under the HECS scheme, debt is incurred by individuals. The taxation system is based on individual income. In the case of the housing lifeline, however, an individual based debt would raise some problems.

The most salient problem has to do with the possibility that only one member of a household earns income. If the housing lifeline were available to individuals, then households would face an incentive for one or more members not to earn income but to utilise the housing lifeline (without the need to ever repay the debt). For this reason, some household-based unit would seem appropriate.

This, in turn, raises other difficulties. For example, issues of liability in case of the break-up of the household need to be considered although lifeline debt could be treated as any other joint household liability in such circumstances.

In addition, a household based scheme would create an incentive for individual members to represent themselves as members of different households. We have no clear solution to this practical problem at this stage. Nonetheless, it should be noted that such problems arise for many social security payments and for the private health insurance rebate. Penalties may have to be imposed and enforced, a registration system may be needed and some means of identifying household-based income would be desired.

\section{Political risks}

Introducing a housing lifeline creates some political risks. In particular, as the total level of debt under a lifeline grows, there might be political pressure to 'write off' the debt.

Such a risk can easily be overstated. First, the risk exists under the current HECS scheme but has not been a significant factor in the Australian education debate. Second, because the lifeline tends to save the federal government money relative to existing welfare programs such as rental assistance, the cost of any write-off or write-down of outstanding debt under the housing lifeline will be less problematic than, say, under the HECS scheme.

\section{Conclusion}

The housing lifeline directly addresses an important problem facing low-income families in a way that is cost effective for government and that avoids creating welfare dependency and poverty traps. The housing lifeline is not about providing new housing solutions for low-income families but rather opens up housing opportunities through the private market for low-income households and helps them to retain appropriate existing housing in the face of temporary setbacks. The policy is about housing insurance. It helps low-income households gain adequate housing with almost no micro-management. It increases choice for low-income households rather than decreasing choice, so it respects the preferences and wishes of individual households. 
The housing lifeline addresses the problems of low-income households facing income fluctuations. It is not aimed at addressing broader housing affordability. While the lifeline will make it more desirable for private investors to develop housing for low-income families, supply constraints on housing may still arise. For this reason, the housing lifeline should be considered in tandem with other policies that help improve general housing affordability, such as the re-evaluation and reform of transaction taxes and planning laws discussed in Caplin et.al. (2003).

The housing lifeline helps to bring private funds to play in low-income housing solutions. In particular, it brings the private funds of the low-income households themselves into the market to provide appropriate housing. Unlike other policies, it does not view low-income households as 'victims' to be 'helped' through benefits funded by others. Rather, it empowers the low-income household and helps them to access their future income rather than just depending on their current low income.

While the government takes on board the risk associated with low-income households, through the housing lifeline insurance, the government is also in a good position to deal with that risk. The government has the substantial advantage of ensuring appropriate repayment of any lifeline loan through the taxation system. A low-income household can use the lifeline in periods of crisis and then would repay the loan when its circumstances improve. This may be in the shortterm or in the longer term, depending on the relevant household's circumstances. For example, modest repayments to the government may begin when household income approaches a set level above poverty-line income.

The housing lifeline avoids artificial constraints on mobility for low-income households, unlike schemes that are tied to particular dwellings. It is highly flexible and the choice of how much or how little of the scheme to use at any point in time is largely up to the relevant household. Thus, while the scheme does not explicitly allow for geographic differences, the household itself can adjust for those differences within the payment bounds set by the government. Further, because it is based on individual household needs, as seen by that household itself, it responds instantly to the changing circumstances of that household.

Finally, the housing lifeline avoids creating poverty traps that harm lowincome households. Indeed, a primary benefit of this scheme is that it would potentially enable to the government to save on social security costs by preventing short-term income problems from transitioning into longer-term poverty.

In summary, the housing lifeline is essentially a government provided insurance product. It has a number of similarities to HECS in that it is based on lifetime income rather than current income, it limits the impost of government funds while providing short-term relief for relevant households and it is a product where benefits are determined by the needs and requirements of the low income household themselves. For these reasons, we believe that it is a policy worthy of close examination by the Federal Government. 


\section{References}

Australian Bureau of Statistics (2002) Yearbook of Australia 2002: Housing prices, Canberra.

Berry, M. and J. Hall (2001), Policy Options for Stimulating Private Sector Investment in Affordable Housing Across Australia, Stage 1 Report: Establishing the Need for Action, Report to Affordable Housing National Research Consortium, Sydney, February.

Caplin, A., C. Joye, P. Butt, E. Glaeser and M. Kuczynski (2003), 'Innovative Approaches to Reducing the Cost of Home Ownership,' Report to the Prime Minister's Home Ownership Taskforce, Menzies Research Centre, Canberra.

Gans, J. and S. King (2003), 'Policy Options for Housing for Low Income Households,' Report to the Prime Minister's Home Ownership Taskforce, Menzies Research Centre, Canberra.

Glaeser, E. and J. Gyourko (2002), 'The Impact of Zoning on Housing Affordability,' Working Paper, No. 8835, NBER.

Stiglitz, J. and A. Weiss (1981), 'Credit Rationing in Markets with Imperfect Information,' American Economic Review, 71 (3):393-410.

Parts of this paper are drawn from our report for the Prime Minister's Taskforce on Home Ownership, 'Policy Options for Housing for Low Income Households' (Gans and King, 2003). This paper benefited greatly from discussions and comments by two anonymous referees, Ed Glaeser, Ian Harper, Elvis Jarnecic, Warwick McKibbin, Adrian Pagan, Malcolm Turnbull and, especially, Chris Joye. Richard Hayes provided outstanding research assistance. We also thank the Menzies Research Centre for financial support. All views expressed here are our own and do not necessarily reflect those of the above individuals and organisations. 